\title{
Reflections on the Integration of Chinese Fine Traditional Culture into Ideological and Political Teaching in Higher Vocational Colleges
}

\author{
Wen Lin \\ Hubei Three Gorges Polytechnic, Yichang, Hubei, China, 443000
}

Keywords: Chinese Fine Traditional Culture; Ideological and Political Education in Higher Vocational Colleges, Integration

\begin{abstract}
Chinese traditional culture can be passed on from generation to generation, from the profound connotation and practical effect of culture itself, such as the thought and virtue of Chinese traditional culture, patriotic sentiments, moral ethics and so on. In the ideological and political education of higher vocational education, it is important to integrate into the fine traditional culture of China and to improve the students' ideological and moral quality. The article briefly summarizes the connotation of Chinese traditional culture, analyzes the significance of traditional culture integration into ideological and political teaching in higher vocational colleges, and then discusses the strategy of integrating traditional Chinese culture into ideological and political teaching in higher vocational colleges.
\end{abstract}

\section{Introduction}

The main purpose of ideological and political education in higher vocational colleges is to help students to establish the correct outlook on life, values and world outlook, and improve the ideological and moral level of students. However, under the influence of the rapid social and economic development, the ideological and political education of higher vocational education is faced with the impact of foreign culture, which makes some Western culture prevail in the country. Many vocational students are keen on Europe and the United States and Korean culture, ignoring the value of local traditional culture. This is unfavorable to the correct values of the student. Therefore, it is very important to integrate the fine traditional Chinese culture into the ideological and political teaching of higher vocational education.

\section{The Connotation of Chinese Fine Traditional Culture}

Fine traditional culture mainly refers to the national nation in the process of the development of historical civilization, the accumulation, precipitation and preservation of the value and vitality of the culture [1]. Chinese fine traditional culture as a whole to Confucian culture as the core, but also contains Taoism, legalists, Mohism and other forms of traditional culture. Traditional culture is the ancient people's valuable spiritual wealth, after a generation of inheritance and carry forward, making the traditional culture to guide the formation of the correct values of modern people. The ideological and political content of traditional culture mainly includes the following aspects: First, the national interests as the core of the patriotism spirit, which is thousands of years to resist the spirit of foreign invaders, such as Gu Yanwu's "rise and fall of the world, Third, to the harmonious ideology as the core of social development momentum; fourth, tenacious struggle of the spirit of quality; fifth, seeking truth from facts and good quality of good faith."Fourth, the spirit of personal quality as the core of the ideological and moral; These fine traditional Chinese culture is of great significance to the formation of modern life, values and world outlook. 


\section{The Significance of the Integration of Chinese Fine Traditional Culture into Ideological and Political Teaching in Higher Vocational Education}

Ideological and political education shoulders the important responsibility of cultivating students' good moral accomplishment [2]. In the ideological and political education of higher vocational education, if the teaching process is confined to the relevant contents stipulated in the syllabus, it is difficult to integrate the fine traditional culture into the actual teaching, and it is often difficult to meet the new situation. The goal of talent and then make ideological and political education is in the important role of moral education.

As a civilized country with a long history and culture of 5,000 years of history, China has been regarded as a classic and influential generation of modern people by modern people and cultivated people with excellent moral character. Therefore, it is necessary to integrate the fine traditional culture into the ideological and political education of higher vocational education, so that the vocational students can learn from the humanities, history, philosophy and other knowledge and nutrition contained in the Chinese culture, which can improve the students' ideological understanding, moral cultivation and National pride to lay a solid foundation for higher vocational ideological and political education to achieve a multiplier effect.

\section{The Way of Integrating Fine Traditional Culture into Ideological and Political Education in Higher Vocational Education}

Ideological and political education in higher vocational colleges is an important task to improve students' ideological and moral level. In order to improve the teaching level of the curriculum, it is necessary to penetrate the fine traditional culture of China into the ideological and political education of higher vocational education. In the actual teaching, it is necessary to always adhere to the student-oriented teaching thought to create a vocational college ideological and political education characteristics of the cultural atmosphere, so that the traditional Chinese culture really affect students' words and deeds.

Teachers Should Lead by Example to Guide Students to Gradually Form A Good Moral Character. Chinese traditional culture is broad and profound, cultural content is inclusive, which fully reflects the wisdom and thought of ancestors, after thousands of years of inheritance, formed a unique culture of China, the national characteristics of significant [4]. At the same time, excellent traditional culture has also been deeply integrated into the people's ideological understanding and behavioral norms, which formed by the traditional culture of the norms are sometimes more deterrent and influence than the law. Therefore, the requirements of the majority of vocational school teachers should inherit and develop Chinese fine traditional culture, through learning these internal culture will continue to be part of their own thinking, so that teachers in the normal teaching can consciously or unconsciously guide students to learn and inheritance Chinese fine traditional culture, so that the traditional culture to give full play to the role of cohesion, cohesion. In addition, the ideological and political teachers in vocational schools should also be practicing, so that the teaching process of "ceremony, justice, benevolence, wisdom, letter" five permanent. For the "ceremony", in the usual teaching, teachers in the gestures should reflect the good cultivation, words and deeds and proper dress, so as to establish a good example for students to guide students to improve and improve their own moral cultivation, such as in class questions, the teacher in the selection of students to answer questions, you can use the "Please answer" words, and students answer questions, suggesting that other students should listen carefully, give students enough respect, after the students answer the question, the teacher and then " Thank the students wonderful answer, please sit ", so that students can feel the teacher's good moral character. For the "righteous" teachers carefully lesson preparation, careful correction of homework and notes approved, to comply with the agreement between students is also a good idea of moral character. Treat students with learning problems, to students to reflect and correct the opportunity. For the "benevolence" can be reflected in the teachers of students in the humanistic care, the teacher should always pay 
attention to the students in the ideological dynamics, timely detection and guidance of students in the ideological and moral aspects of the problem, to give students learning and life can help [ 5]. For the "wisdom" teachers need to maintain life-long learning, pay attention to the actual teaching process with a wealth of professional knowledge to obtain the recognition and approval of students, rational view of the problem, to guide students' rational thinking. For the "letter" will need teachers to make words and letters, on time to reach the agreed teaching location. Do the teaching of the "five permanent", to enable teachers to arouse students to learn and carry forward the enthusiasm of Chinese fine traditional culture, thereby enhancing the ideological and moral quality of students.

According to the Status Quo of Ideological and Political Education, Select the Appropriate Cultural Import Timing. In the global integration of the development trend, the state and the country more and more cooperation between the exchanges, which also makes a large influx of foreign culture to the country, which opened up the vision of vocational students, enrich the students in the spiritual world. However, a large number of foreign cultures also affect the values of vocational students, the phenomenon of exorcism is extremely serious, mainly because many vocational students lack of cultural screening ability, often for the foreign culture, according to the whole, ignoring the future culture of dross, so that students in turn on the local culture of disgust, which students a good moral character of the formation of adverse.

In view of the problems existing in the ideological and moral aspects of higher vocational students, teachers are required to introduce Chinese fine traditional culture in ideological and political teaching in time to disperse the dross of foreign culture with Chinese fine traditional culture. For example, in explaining the patriotism, teachers can introduce Qi Jiguang to fight against foreign enemies, "the rise and fall of the world, every man is responsible", "bit the humble country" and other historical events and famous aphorisms, so that through historical examples and classic words to guide students For the correct patriotism, so that students really realize that in the country at the time of the crisis, some of the followers of the people with lofty ideals for the benefit of the country dedicated their lives. Through the introduction of timely and traditional culture, the traditional Chinese traditional culture into the students 'thoughts, and internalization into the motive force of students' own progress, makes the ideological and political teaching of higher vocational education is more targeted and effective.

Carry Out Practical Teaching and Make the Traditional Culture Deeply into the Minds of Students. Ideological and political education in higher vocational education bears the effectiveness [6]. To this end, teachers are required to carry out ideological and political education, should carry out practical teaching, in the course of practice into Chinese fine traditional culture, and promote the improvement of students' moral quality. For example, teachers can carry out the "respect for the young" as the main social practice, so that students concerned about the current social emerging two groups: left-behind children and empty nest elderly. Left-behind children because of their parents' perennial, in the family care and academic counseling there are some problems which makes a lot of left-behind children there are cold, autistic psychological barriers, it is difficult to integrate into the collective life and learning. Therefore, the ideological and political teachers in vocational colleges can take full advantage of spare time or holidays, to lead students to visit and care about children left behind and empty nests for the children to send some homemade small gifts to help children make up classes, and empty nesters to communicate, performance programs, so that these children and the elderly can feel the love of others. Through this practice teaching, students can be in the process of personal experience, inheritance and carry forward the fine traditional Chinese culture to help others, respect for the fine tradition of young people, change the students' thinking, and promote the formation of good thinking quality of students.

Integrate Teaching Materials and Optimize the Classroom Teaching Structure. Ideological and political education in higher vocational colleges faces the prominent problems such as large capacity of teaching materials, complicated contents and less teaching time. And if the requirements of ideological and political education teachers in the teaching of traditional cultural content are bound to take some time, may make teachers unable to complete the teaching objectives in the specified time [7]. In view of this situation, the majority of ideological and political teachers in 
vocational colleges should be planned, purposefully delete or increase the relevant content of teaching materials, the fine traditional Chinese culture and ideological and political teaching organically combine to optimize the ideological and political teaching structure, Improve the teaching effect of the course.

In teaching methods, teachers should also be able to keep pace with the times, make full use of modern teaching methods and teaching aids, and stimulate students to learn the enthusiasm. Among them, the teaching methods are more prominent methods, including multimedia courseware to explain, group cooperative learning, pre-class lectures, compared to the traditional classroom teaching, with multimedia aids to teach, you can give students a more intuitive understanding, so that students better understand the fine tradition of China culture, so that teachers can in a limited time will be the most abundant knowledge passed to the students; and group cooperative learning is to change the teacher a single teaching style of teaching, give full play to the initiative of the students, through group cooperation to explore and deepen students' knowledge understanding; pre-class lectures can be students in the ancient poems contained in the ideological and emotional and excellent culture, on the one hand so that students feel the fine traditional Chinese culture contains the unique charm, on the other hand can also stimulate students to continuously enhance the enthusiasm of the self , And constantly regulate their own words and deeds, so as to form a harmonious, friendly, mutual help each other ideological and political classroom atmosphere.

\section{Conclusion}

In short, in order to improve the quality of ideological and political education in higher vocational education, it is necessary to truly integrate the fine traditional culture of China into the ideological and political teaching in the course of teaching, and also ask the relevant ideological and political teachers to do the work, pay attention to the students to guide correctly, Take the teaching method of advancing with the times, improve the enthusiasm of students to learn, so as to improve the ideological and moral quality of vocational students, and truly cultivate a group of talents for both talents.

\section{References}

[1] Luo Min. On the ideological and political education in higher vocational education and the integration of tea culture [J]. Fujian tea, 2017, 23 (03): 234-235.

[2]. On the construction of China's oil ideological and political security system (on) [J] .Enterprise civilization, 2011, 14 (03): 33-37.

Journal of Jinan Vocational College, 2014,15 (01): 25-27 (in Chinese with English abstract) [J]. Journal of Jinan Vocational College, 2014, 15 (01): 25-27.

[4] Hu Sianlian, Wang Yakun.Study on the Influence of Higher Vocational Education on Ideological and Political Education [J]. Drama House, 2017, 22 (04): 226.

[5] Li Ni, Wang Kunrong. Chinese excellent traditional culture into the ideological and political theory of higher vocational school teaching research[J]. Education and Teaching Forum, 2017,8 (23): 253-254.

[6] Zhang Yaqiong, Tan Ting, Peng Miao. University of Chinese fine traditional culture education[J]. Chinese and foreign entrepreneurs, 2016, 6 (20): 153-154.

[7] Xu Liang, Wang Wen. On the party's ideological and political education under the guidance of fine tradition of college students ideological and political education work [He] Heihe Journal, 2012,14 (01): 58-59. 